\title{
PENGARUH PENDIDIKAN KESEHATAN PRANIKAH TERHADAP PENGETAHUAN DAN SIKAP CALON PENGANTIN DI LUBUK BEGALUNG PADANG TAHUN 2017
}

\author{
Dewi Susanti,Yefrida Rustam, Alsri Windra Doni \\ (Politeknik Kesehatan Kemenkes Padang)
}

\begin{abstract}
Divorce rates in Indonesia in the last five years show a significant number where Indonesia ranks fifth with 276,791 cases. The purpose of this study was to determine the effect of premarital health education on the knowledge and attitudes of brides in Lubuk Begalung Subdistrict, Padang City in 2017. The type of research was quasy experiment with pretestposttest design. The study was conducted in KUA Lubuk Begalung District in AprilJune2017. Population in this research bride and groom who came to KUA Lubuk Begalung District during the research period were 19 couples taken by purposive sampling. Data collection used questionnaires given before and after health education. Data analysis was done by univariate and bivariate using Wilcoxon statistical test with computer. Results Research on 38 prospective brides showed that $31.6 \%$ of respondents were low knowledge before premarital education and $97.4 \%$ were highly knowledgeable after premarital education, $76.3 \%$ were negative before premarital education. There is the influence of premarital education on the knowledge and attitudes of the bride and groom ( $p$ value 0.001 and 0.013) Conclusion there is the effect of premarital health education on the knowledge and attitudes of brides in the District of Lubuk Begalung Padang in 2017.
\end{abstract}

Keywords: Knowledge, Attitude, Pre-marital Health Education, Bridal Candidate.

\begin{abstract}
Abstrak
Angka perceraian di Indonesia dalam lima tahun terakhir menunjukkan angka yang cukup signifikan dimana Indonesia menempati urutan kelima dengan 276.791 kasus. Tujuan Penelitian ini untuk mengetahui pengaruh pendidikan kesehatan pranikah terhadap pengetahuan dan sikap calon pengantin di Kecamatan Lubuk Begalung Kota Padang Tahun 2017.Jenis penelitian quasy eksperimen dengan rancangan pretest-posttest design.Penelitian dilakukan di KUA Kecamatan Lubuk Begalung pada bulan AprilJuni2017.Populasi dalam penelitian ini calon pengantin yang datang ke KUA Kecamatan Lubuk Begalung selama waktu penelitian sebanyak 19 pasangan yang diambil secara purposive sampling.Pengumpulan data menggunakan kuisioner yang diberikan sebelum dan sesudah pendidikan kesehatan.Analisis data dilakukan secara univariat dan bivariat menggunakan uji statistik Wilcoxon dengan komputer. Hasil penelitian terhadap 38 calon pengantin menunjukan bahwa $31,6 \%$ responden berpengetahuan rendah sebelum pendidikan pranikah dan 97,4\% berpengetahuan tinggi setelah pendidikan pranikah, 76,3\% bersikap negative sebelum pendidikan pranikah. Ada pengaruh pendidikan pranikah tehadap pengetahuan dan sikap calon pengantin ( $p$ value 0,001 dan 0,013) Kesimpulan ada pengaruh pendidikan kesehatan pranikah terhadap pengetahuan dan sikap calon pengantin di Kecamatan Lubuk Begalung Padang Tahun 2017.
\end{abstract}

Kata Kunci : Pengetahuan, Sikap, Pendidikan Kesehatan Pranikah, CalonPengantin. 


\section{PENDAHULUAN}

Kasus perceraian sudah menjadi fenomena yang banyak terjadi pada saat sekarang ini, Berdasarkan data Demografi Departemen Urusan Ekonomi dan Sosial Persatuan Bangsa Bangsa, kasus perceraian di dunia tahun 2012 mencapai 5.685 .602 kasus. Sementara itu di tahun 2011 Cina merupakan angka perceraian tertinggi di dunia yaitu sebanyak 2.111.000 kasus, diikuti oleh Amerika Serikat dengan 877.000 kasus, kemudian Rusia dengan 669.376 kasus, selanjutnya Jepang dengan 235.719 kasus. Indonesia menempati urutan kelima dengan 276.791 kasus perceraian.Angka perceraian di Indonesia dalam lima tahun terakhir menunjukkan angka yang cukup siknifikan. Berdasarkan data tahun 2010 - 2014 , dari sekitar dua juta pasangan menikah maka pasangan yang melakukan perceraian di pengadilan agama jumlahnya mencapai sekitar tiga ratus ribu lebih atau $15 \%$ atau lebih. Perceraian tersebut dilakukan oleh suami maupun istri dengan berbagai alasan.

Dari data perceraian yang ada di Badan Peradilan Agama (Badilag) Mahkamah Agung (MA) RI, alasan tidak lagi ada keharmonisan menjadi angka terbesar.Kemudian alasan tidak ada tanggung jawab, alasan ekonomi, dan gangguan pihak ketiga.Pada tahun 2015 angka perceraian tertinggi juga terjadi di Kota Padang dengan jumlah perceraian sebanyak 1.044 kasus, kemudian Kota Payakumbuh 568 pasangan, dan Pariaman 530 pasangan. Daerah tingkat perceraian terendah yakni Agam 166 pasangan, Pesisir Selatan 183 pasangan, serta Solok Selatan 194 pasangan. Tingginya kasus perceraian selama tiga tahun terakhir disebabkan faktor ekonomi lemah, sehingga menimbulkan masalah dalam rumah tangga antara suami istri yang berujung perceraian.Berdasarkan data Pengadilan Agama kasus perceraian terbanyak di Kota Padang pada tahun 2015 terjadi di Kecamatan Koto Tangah, yakni sebanyak 235 kasus. Disusul Lubuk Begalung 201 kasus, dan Kuranji 173 kasus.Pemerintah telah memiliki sebuah sarana yang dicanangkan untuk mengurangi dan bahkan mencegah terjadi perceraian khususnya di lingkungan masyarakat muslim yaitu Badan Penasihatan Pembinaan dan Pelestarian Perkawinan (BP4) dengan perangkat Pendidikan Calon Pengantin (SUSCATIN) Oleh karena itu, dalam rangka menghindari persepsi pasangan suami-istribahwasannya pembagian peran rumah tangga merupakan sesuatu yang baku, danselanjutnya juga diharapkan dapat mengurangi tingginya angka perceraian dilndonesia, maka di sini peran Pendidikan calon pengantin sangat menentukan.Dengan memberikan Kursus calon pengantin adalah pemberian bekal pengetahuan, pemahaman dan ketrampilan, dalam waktu singkat kepada calon pengantin tentang kehidupan rumah tangga/ keluarga, dan kesehatan Pranikah. Hal ini merujuk pada Peraturan Dirjen Bimas Islam No.DJ.II/491 Tahun 2009 sebagai dasar hukumnya.Jadi, pada dasarnya suscatin merupakan upaya yang dilakukan oleh pemerintah yang dalam hal ini 
BP4 untuk membekali calon pengantin dalam menyongsong mahligai rumah tangga agar dalam praktek rumah tangga nanti keduanya ataupasangan suami isteri memiliki dan mampu menerapkan bekal psikis dan ketrampilan dalam menghadapi setiap problematika keluarga. Dengan demikian, cita-cita terbentuknya keluarga yang sakinah, mawaddah, dan warrahmah akanlebih mudah tercapai dan sekaligus terwujud pula masyarakat yang harmonis, serta terhindar dari konflik dan perceraian. Pembekalan diberikan kepada calon pengantin dengan waktu tertentu yaitu selama 24 jam pembelajaran. Pendidikan calon pengantin sangat berperan penting untuk meningkatkan bekal calon pengantin salah satunya adalah pengetahuan tentang kesehatan Pranikah.Dimana dengan pemahaman yang cukup mengenai kesehatan Pranikah, calon pengantin dapat menjalani pernikahan yang sehat dan aman.Calon pengantin perlu dibekali pengetahuan yang cukup tentang kesehatan Pranikah dan hak-hak Pranikah sehingga calon pengantin siap menjadi seorang ibu dan seorang ayah.

Hidayati (2016) dalam penelitiannyayang berjudul hubungan tingkat pengetahuan tentang kesehatan Pranikah dengan kesiapan menikah pada calon pengantin. Menunjukkan calon pengantin dengan tingkat pengetahuan kesehatan Pranikah baik sebagian besar siap menikah sebanyak 15 orang dengan kategori siap 10 orang $(66,7 \%)$ dan tidak siap 5 orang $(33,3 \%)$. Sedangkan calonpengantin dengan tingkat pengetahuan kesehatan Pranikah cukup 15 orang dengan kategori siap 9 orang (60\%) dan tidak siap 6 orang (40\%). Dan calon pengantindengan tingkat pengetahuankesehatan Pranikah kurang 20 orang, dengan kategori siap 5 orang (25\%) dan tidak siap 15 orang (75\%).

Dalam penelitian Aryani $\mathrm{Y}$ (2015) di Kota Tarakan, tentang analisiskebutuhan konseling pranikah tentang kesehatan reproduksi. Menunjukkan pengetahuan calon pengantin tentang kesehatan reproduksi secara keseluruhan berkategori baik sebanyak 35 orang $(68,6 \%)$ dan pengetahuan cukup sebanyak 16 orang $(31,4 \%)$. Pelaksanaan konseling pranikah di Kota Tarakan secara umum dalam kategori cukup sebanyak 17 tempat pelaksana $(80,95 \%)$ dan kategori kurang sebanyak 4 tempat pelaksana (19,05\%) yang dinilai mencakup kebijakan, SDM (Sumber Daya Manusia), sarana/prasarana, pedoman; waktu, lama, metode, media dan materi. Adapun kebutuhan konseling pranikah tentang kesehatan reproduksidi Kota Tarakan 90,48\% sangat membutuhkan untuk dilakukan konseling di fasilitas pelayanan pernikahan. Berdasarkan survey awal yang dilakukan di KUA Kecamatan Lubuk Begalung Kota Padang dengan melakukan wawancara kepada 5 pasangan calon pengantin ,bahwa rata-rata tidak paham tentang kesehatan reproduksi. Dari data pendaftaran pernikahan, diketahui rata-rata pasangan yang mendaftarkan diri untuk Menikah berkisar antara 50-100 pasangan perbulan dengan jumlah yang mengikuti sidang 2 kali dalam seminggu yaitu hari selasa dan rabu kurang lebih 6 pasangan. Berdasarkan 
masalah yang terlihat peneliti akan meneliti Pengaruh Pendidikan Kesehatan Pranikah terhadap Tingkat Pengetahuan dan Sikap Calon Pengantin di Kecamatan Lubuk Begalung Padang.

\section{METODE PENELITIAN}

Penelitian ini bersifat eksperimen semu (Quasi Eksperimen) dengan rancangan one group pretest posttest dilaksanakan di Kantor Urusan Agama (KUA) Kecamatan Lubuk Begalung Padang pada bulan November - Desember 2018. Populasi pada penelitian ini adalah seluruh calon pengantin yang datang ke KUA Kecamatan Lubuk Begalung sebanyak 38 orang diambil secara purposive sampling dengan caramemilih sampel atas pertimbangan peneliti yang dapat mewakili populasi.yang memenuhi kriteria sbb:

Kriteria Inklusi:

a. Bersedia menjadi responden

b. Merupakan pernikahan pertama

Kriteria Eksklusi: Tidak bersedia mengikuti Pendidikan calon pengantin tentang kesehatan Pranikah.

Alat yang digunakan dalam penelitian ini adalah kuesioner dan panduan leaflet untuk mengukur dan pemberian pengetahuan serta sikap dari Calon Pengantin tentang Kesehatan Pranikah. Data didapatkan langsung dari KUA Lubuk Begalung Padang.Analisa univariat didapatkan secara deskriptif dari pengaruh pendidikan kesehatan yang diberikan.Analisa bivariat dengan menggunakan Uji Wilcoxon pada program komputerisasi.

\section{HASIL PENELITIAN}

Berdasarkan hasil penelitian yang dilakukan tentang pengaruh pendidikan kesehatan pra nikah terhadap tingkat pengetahuan dan sikap calon pengantin di kecamatan lubuk begalung padang dengan jumlah responden 38 orang, didapatkan hasil penelitian sebagai berikut :

Tabel 1.Distribusi Responden Berdasarkan Tingkat Pengetahuan

\begin{tabular}{cccc}
\hline No & $\begin{array}{c}\text { PengetahuanCalon } \\
\text { Pengantin }\end{array}$ & $\mathrm{N}$ & $\%$ \\
\hline 1 & Rendah & 12 & 31,6 \\
\hline 2 & Tinggi & 26 & 68,4 \\
\hline & Jumlah & 38 & 100 \\
\hline
\end{tabular}

Berdasarkan tingkat pengetahuan dapat diketahui bahwa banyak responden yang memiliki pengetahuan tinggi tentang kesehatan pranikah yaitu 26 orang $(68,4 \%)$. 
Tabel 2. Distribusi responden berdasarkan sikap

\begin{tabular}{llll}
\hline No & Sikap calon pengantin & N & $\%$ \\
\hline 1 & Positif & 29 & 76,3 \\
\hline 2 & Negatif & 9 & 23,7 \\
\hline & Jumlah & 38 & 100 \\
\hline
\end{tabular}

Berdasarkan sikap responden didapati yang memiliki sikap positif lebih banyak dari yang bersikap negatif yaitu 29 orang $(76,3 \%)$.

Tabel 3.Pengaruh Pendidikan Kesehatan Pranikah terhadap Tingkat Pengetahuan

\begin{tabular}{llll}
\hline Variable & N & Mean & P value \\
\hline Pengetahuan & 38 & 66 & 0,001 \\
\hline
\end{tabular}

Berdasarkan tabel 3 didapatibahwa terdapat pengaruh pemberian pendidikan kesehatan pranikah terhadap pengetahuan calon pengantin di Kecamatan Lubuk Begalung Kota Padang dengan rata-rata pengetahuan responden adalah $66, p$ value $0,001<\alpha 0,05$

Tabel 4.Pengaruh Pendidikan Kesehatan Pranikah terhadap Sikap

\begin{tabular}{cccc}
\hline variabel & $\mathbf{N}$ & Mean & P value \\
\hline Sikap & 38 & 77 & 0,013 \\
\hline
\end{tabular}

Tabel diatas didapati bahwa terdapat pengaruh pemberian pendidikan kesehatan pranikah terhadap sikap calon pengantin di Kecamatan Lubuk Begalung Kota Padang dengan rata- rata sikap responden $77, p$ value $0,013<\alpha 0,05$

\section{PEMBAHASAN}

Berdasarkan hasil analisis univariat dilakukan pada calon pengantin di Kecamatan Lubuk Begalung Kota Padang mengenai tingkat pengetahuan tentang kesehatan pranikah sebelum diberikan pendidikan kesehatan, dari 38 responden yang memiliki pengetahuan rendah 12 responden $(31,6 \%)$ dan memiliki pengetahuan tinggi sebanyak 26 responden (68,4\%). Hal ini salah satunya dapat disebabkan karena tingkat pendidikan dan umur responden sehingga kurang terpapar dengan pentingnya pendidikan pranikah.

Penelitian ini sejalan dengan penelitian yang dilakukan oleh Hidayati Rtentang hubungan tingkat pengetahuan tentang kesehatan reproduksi dengankesiapan menikah pada calon pengantin di Yogyakarta tahun 2016, menunjukkan bahwa ada pengaruh tingkat pengetahuan kesehatan reproduksi dengan kesiapan menikah pada calon pengantin dimana di jelaskan dalam uji statistik $p$ value $0,027<0,05$.

Dari suatu penelitian eksperimen tentang pengaruh pendidikan kesehatan tentang nutrisi prakonsepsi terhadap tingkat pengetahuan dan sikap konsumsi makanan sehat 
pranikah di Yogyakarta 2012 menunjukkan bahwa ada pengaruh antara pengetahuan sebelum dan sesudah diberikan pendidikan kesehatan dengan nilai $p=0,039<0,05$.

Berdasarkan analisis bivariat dilakukan uji normalitas yaitu pada tingkat pengetahuan dan sikap calon pengantin yang tidak berdistribusi normaldimana tingkat pengetahuan dan sikap telah dilakukan uji statistik ( $p$ value $0,005<0,05$ ) dan ( $p$ value $0,010<0,05$ ). Oleh karena itu untuk melihat pengaruh pendidikan kesehatan pranikah terhadap tingkat pengetahuan dan sikap calon pengantin menggunakan Uji Wilcoxon.Menurut teori yang pendidikan dan perilaku Notoatmodjo, pengetahuan dipengaruhi oleh beberapa faktor seperti umur, pengalaman, pekerjaan, lingkungan, sosial budaya, informasi dan pendidikan. Semakin baik tingkat pendidikan dan pekerjaan seseorang, akan semakin baik pula pengetahuan dan keterampilan yang dimiliki. Hasil penelitian ditemukan bahwa ada pengaruh pendidikan kesehatan pranikah terhadap tingkat pengetahuan calon pengantin ( $p$ value 0,001) di Kecamatan Lubuk Begalung Kota Padang tahun 2017. Penelitian ini hampir sama dengan penelitian yang dilakukan oleh Fauzia $A$ tentang pengaruh pendidikan kesehatan tentang nutrisi prakonsepsi terhadap tingkat pengetahuan dan sikap konsumsi makanan sehat pranikah di Yogyakarta 2012 menunjukkan bahwa ada pengaruh antara pengetahuan sebelum dan sesudah diberikan pendidikan kesehatan dengan nilai $p=0,039<$ 0,05 . Hasil penelitian ditemukan bahwa ada pengaruh pendidikan kesehatan pranikah terhadap sikap calon pengantin ( pvalue 0,035) di Kecamatan Lubuk Begalung Kota Padang.

Penelitian ini hampir sama dengan penelitian yang dilakukan oleh Kirana Ntentang hubungan konseling Pranikah bagi calon pengantin di Kota Yogyakarta tahun 2016, menunjukkan bahwa ada hubungan yang positif signifikan antara konseling pranikah pada calon pengantin dimana nilai rhitung sebesar 0.549 dengan $p=0,0000<0,05$. Penelitian ini hampir sama dengan penelitian yang dilakukan oleh Fauzia $A$ tentang pengaruh pendidikan kesehatan tentang nutrisi prakonsepsi terhadap tingkat pengetahuan dan sikap konsumsi makanan sehat pranikah di Yogakarta 2012 menunjukkan bahwa ada pengaruh antara sikap sebelum dan sikap sesudah diberikan pendidikan kesehatan dengan nilai $p=0,03<0,05$. Sikap merupakan kesiapan atau kesediaan seseorang dalam bertindak. Sikap belum merupakan tindakan atau aktifitas, akan tetapi merupakan predisposisi daritindakan atau prilaku. Suatu sikap belum otomatis terwujud dalam tindakan.Perludiketahui bahwa sikap calon pengantin merupakan pendukung dalam kesiapannya dalam menghadapi mahligai rumah tangga.Menurut asumsi peneliti sikap seseorang bisa di pengaruhi oleh umur dan tingkat pendidikan dapat dilihat berdasarkan karakteristik responden dimana sebagian responden sudah memiliki sikap yang positif setelah dilakukan pendidikan kesehatan 
pranikah karena usia responden yang sudah matang untuk menikah dan pendidikan responden juga menentukan sikap seseorang.

\section{SIMPULAN DAN SARAN}

Berdasarkan hasil penelitian disimpulkan bahwa ada pengaruh yang signifikan antara pendidikan kesehatan pranikah terhadap tingkat pengetahuan dan sikap calon pengantin di Kecamatan Lubuk Begalung Kota Padang.Hal ini dikarenakan media pendidikan kesehatan dapat memperluas pemikiran responden dalam menyingkapi masalah serta menambah atau meningkatkan wawasan mengenai pendidikan kesehatan pranikah.

Berdasarkan hasil penelitian disarankan kepada petugas KUA harus lebih tegas lagi dalam pengumpulan persyaratan pernikahan, sesuai standar pernikahan.Bagi institusi pendidikan ini dapat menjadi bahan masukan menambah informasi terkait masalah pranikah.Bagi calon pengantin atau Pasangan yang hendak melakukan pernikahan sebaiknya tidak meyepelekan pendidikan pranikah dan pemeriksaan kesehatan sebab banyak penyakit yang tidak kelihatan sekarang tetapi nantinya ketika dalam berumah tangga dapat ditularkan kepada pasangan atau di turunkan pada anak nantinya.Harus bisa menyempatkan waktu untuk dapat mengikuti kegiatan pendidikan pranikah dan menyadari urgensi pendidikan pranikah sebagai bekal dalam mengarungi bahtera rumah tangga.

\section{DAFTAR PUSTAKA}

Sari, Elvina.Bagaimana Gambaran Proses Pengambilan Keputusan Bercerai pada Perempuan Minangkabau. Padang:2016

Catatan Tahunan. Komisi Nasional Anti Kekerasan terhadap Perempuan.Jakarta: 2016

Badan Pusat Statitik Indonesia.Tentang Perceraian dan Talak. Jakarta: 2015

Na'mah U. Pentingnya Peran Suscatin dalam Membendung Laju Perceraian. Jakarta: 2016

Hidayati RD. Hubungan Tingkat Pengetahuan terhadap Kesehatan Reproduksi dengan

Kesiapan Menikah pada Calon Pengantin.Yokyakarta:2016

Susanti D, Rustam Y. Pengaruh Kursus Kesehatan Reproduksi Terhadap Pengetahuan dan

Sikap Calon Pengantin di Kecamatan Koto Tangah. Padang: 2016

Dinas Kesehatan. Padang: 2015 Kementrian Pemberdayaan Perempuan dan Perlindungan Anak RepublikIndonesia: 2016

Nadesul H. Kiat Sehat Pranikah. Jakarta: Pt Kompas Nusantara; 2009

Marmi. Kesehatan Reproduksi. Yokyakarta: Trans Info Media ; 2013

Yanti.Buku Ajar Kesehatan Reproduksi. Yokyakarta: Pustaka Rihama; 2011

Kementrian Kesehatan. Lembar Balik Kesehatan dan Seksual Bagi Calon Pengantin. Jakarta; 2014 
Sulistyawati A. Asuhan Kebidanan pada Masa Kehamilan. Jakarta: Salemba Medika; 2011

Setiyaningrum E, Aziz BZ. Pelayanan Keluarga Berencana dan Kesehatan Reproduksi. Jakarta: Trans Info Media; 2014

Purwoastuti E, Walyani ES.Panduan Materi Kesehatan Reproduksi dan Keluarga Berencana. Yokyakarta: Pustaka Baru Press; 2015

Notoatmodjo S. IImu Perilaku Kesehatan. Jakarta: Rineka Cipta; 2014

Budiman, Riyanto A. Kapita Selekta Kuesioner Pengetahuan dan Sikap dalam Penelitian. Jakarta: Salemba Medika; 2013

Sarwono SW. Pengantar Psikologi Umum. Jakarta: PT Raja Grafindo Persada; 2009

Wawan A, Dewi M. Teori dan Pengukuran Pengetahuan Sikap dan Perilaku Manusia. Yokyakarta: Nuha Medika; 2011

Walgito B. Psikologi Sosial Suatu Pengantar. Yokyakarta: Andi Offset; 2003

Arikunto S. Prosedur Penelitian Suatu Pendekatan Praktik. Jakarta: Rineka Cipta; 2010

Setiwan A, Saryono. Metodologi Penelitian Kebidanan DIII,DIV,SI dan

Yokyakarta: Nuha Medika; 2011

Profil KUA Lubuk Begalung. Padang: 2015

Wahana.Solusi Mudah dan Cepat Menguasai SPSS untuk Pengolahan Data Statistik. Jakarta: 2009

Rahim R. Pengetahuan dan Sikap Wanita tentang Kesehatan Reproduksi dengan Kursus Calon Pengantin. Yokyakarta: 2016

Kirana N. Hubungan Layanan Konseling BP4 pada Pasangan Calon Pengantin dengan Kesiapan Fisik Pranikah. Yokyakarta: 2016

Fauziyah A. Pengaruh Pendidikan Kesehatan tentang NutrisI Prakonsepsi terhadap Tingkat Pengetahuan dan sikap konsumsi makanan wanita pranikah.Yogyakrta : 2012 